\title{
Effect of pH adjustment on the composition and rennet-gelation properties of milk concentrates made from ultrafiltration and reverse osmosis
}

\author{
A. Lauzin, ${ }^{1}$ A. Bérubé, ${ }^{1}$ M. Britten, ${ }^{2}$ and Y. Pouliot ${ }^{1 *}$ \\ ${ }^{1}$ STELA Dairy Research Center, Institute of Nutrition and Functional Foods (INAF), Department of Food Science, Université Laval, Québec, \\ Canada G1V OA6 \\ ${ }^{2}$ St-Hyacinthe Food Research Center (SHFRC), Agriculture and Agri-Food Canada, St-Hyacinthe, Canada J2S 8E3
}

\section{ABSTRACT}

The objective of this work was to investigate the effect of $\mathrm{pH}$ adjustment (initial $\mathrm{pH}$ vs. $\mathrm{pH}$ 6.50) on the rennet-gelation properties of concentrates made by ultrafiltration (UF) and reverse osmosis (RO). Rennetgelation kinetics were followed by dynamic rheology and $\kappa$-casein hydrolysis by reverse-phase HPLC. At initial $\mathrm{pH}, \mathrm{RO}$ concentrates had better rennet-coagulation behavior than UF concentrates and skim milk, whereas adjusting the $\mathrm{pH}$ to 6.50 produced the opposite results. The kinetics of $\kappa$-casein hydrolysis were similar in skim milk, and both concentrates and were not affected by $\mathrm{pH}$ adjustment. Differences in rennet coagulation were then related to the extent of hydrolysis required to trigger casein micelle aggregation. Small $\mathrm{pH}$ adjustments $(<0.2 \mathrm{pH}$ unit) enabled the use of RO concentrate with similar rennet-gelation behavior to UF concentrate, despite major compositional differences. This study shows that $\mathrm{pH}$ adjustment of $\mathrm{RO}$ concentrates can be a simple approach to improve their coagulation properties; however, the mechanisms behind these improvements remain to be elucidated.

Key words: reverse osmosis, ultrafiltration, rennet coagulation, $\kappa$-casein hydrolysis, $\mathrm{pH}$

\section{INTRODUCTION}

Cheese milk concentration using pressure-driven membrane filtration is widespread in the dairy industry and has several advantages over other methods, such as higher cheese yields and lower environmental impact due to reduced whey production. The most common processes used are UF and microfiltration (Mistry and Maubois, 2004), but other processes, such as reverse osmosis (RO), could be useful from an environmental standpoint. Indeed, whereas UF permeate contains lactose and soluble milk minerals, the permeates obtained

Received October 25, 2018.

Accepted January 14, 2019.

*Corresponding author: Yves.Pouliot@fsaa.ulaval.ca with RO are almost pure water (Gaucheron et al., 2004) and can be easily handled and used as process water in dairy plants. Furthermore, gas emissions related to transportation can be reduced by milk concentration using the RO process. To take advantage of the benefits and optimize the use of the RO process, it is necessary to gather more information about the behavior of $\mathrm{RO}$ concentrate during the steps of cheesemaking.

The rennet coagulation of milk is the first step of cheesemaking and is of importance, as it affects the whole process and the final cheese (Wium et al., 2003; Ong et al., 2011; Soodam and Guinee, 2018). As milk composition has an major effect on the gelation behavior and on the whole cheesemaking process, cheese milk composition is often standardized to decrease the need of adjusting the process and decrease variations in cheese yield and quality. This standardization step is realized with the use of dairy powders, such as skim milk powder or high-protein dairy powder, or with the use of milk concentrate (Soodam and Guinee, 2018). The use of UF concentrates for cheesemaking has received much attention and is well understood. Using UF concentrate rather than skim milk (SM) changes the rennet-gelation behavior, and it is generally accepted that it leads to higher firming rates and higher final gel firmness than SM (Waungana et al., 1998; Mistry and Maubois, 2004; Sandra et al., 2011). This is due to the higher number of bonds between caseins and to the closer proximity of casein micelles due to protein concentration. Conflicting results have been reported about the effect of protein concentration and $\mathrm{pH}$ on coagulation time: the rennet coagulation time (tlag) was either not affected, shorter, or longer (Guinee et al., 1997; Waungana et al., 1998; Karlsson et al., 2007a; Sandra et al., 2011). The coagulation time takes into account both the enzymatic phase, during which rennet cleaves the Phe-Met bonds on $\kappa-\mathrm{CN}$, resulting in the release of caseinomacropeptide, and the aggregation phase, which starts when a certain degree of hydrolysis is reached (Dalgleish, 1980). Some authors have reported that the degree of $\kappa$-CN hydrolysis at the coagulation point was independent of protein content 
(Sandra et al., 2011), whereas others have shown a reduced degree of $\kappa-\mathrm{CN}$ at the coagulation point while increasing the concentration factor of the milk (Sharma et al., 1993; Karlsson et al., 2007b).

We have previously shown that, at the same protein content and similar $\mathrm{pH}, \mathrm{RO}$ concentrate led to different rennet-gelation properties compared with UF concentrate. In $\mathrm{RO}$ concentrate, longer coagulation time, lower firming rate, and higher gel firmness were observed (Lauzin, et al., 2018). The main compositional difference between UF and RO concentrates is the higher concentration of soluble salts and lactose in $\mathrm{RO}$ concentrate, which increases the viscosity and ionic strength of the serum phase. These factors could be responsible for the differences observed for rennetinduced gelation properties.

During cheesemaking, the $\mathrm{pH}$ of cheese milk is decreased slightly before renneting, which speeds up the coagulation process (Zoon et al., 1989). Decreasing the $\mathrm{pH}$ leads to the solubilization of colloidal calcium phosphate, which increases ionic calcium activity in the serum phase (Shalabi and Fox, 1982) and slightly neutralizes the negative charge of the micelles. These factors reduce the electrostatic repulsions between casein micelles and promote close contacts, which increases the aggregation rate between paracaseins. The rennet activity is also increased at lower $\mathrm{pH}$ and the $\kappa-\mathrm{CN}$ hydrolysis rate is higher (Lucey et al., 2003). Hence, lowering $\mathrm{pH}$ affects both the hydrolysis and aggregation phases by modifying the interaction balance between micelles and changing the salt equilibrium. The gelfirming rate and the final firmness also increased when the pH was lowered (Zoon et al., 1989; Awad, 2007).

In our previous study, we demonstrated that the initial $\mathrm{pH}$ of RO concentrate was lower (6.31) than that of UF concentrate or SM (about 6.57; Lauzin et al., 2018). The rennet-gelation properties were studied at $\mathrm{pH} 6.50$, which was higher than the initial $\mathrm{pH}$ of $\mathrm{RO}$ concentrate. The effect of $\mathrm{pH}$ adjustment is well known for SM and UF concentrate, but not for RO concentrate. To optimize the use of $\mathrm{RO}$ concentrate in cheesemaking, the rennet-gelation properties at initial $\mathrm{pH}$ and the effect of $\mathrm{pH}$ adjustment must be determined. The goal of this study was to compare the rennet-gelation properties of $\mathrm{RO}$ and UF concentrates at their natural $\mathrm{pH}$ and after adjustment to $\mathrm{pH} 6.50$.

\section{MATERIALS AND METHODS}

\section{SM Supply and Concentration}

Pasteurized $\left(72^{\circ} \mathrm{C}, 15 \mathrm{~s}\right) \mathrm{SM}$ was supplied from a local dairy factory. Skim milk was stored at $4^{\circ} \mathrm{C}$ until concentrated or analyzed. For each replicate, all concentrates were made from the same SM batch.

Milk was concentrated using a filtration pilot system (Model 1812 Lab Unit, Filtration Engineering Company, Champlin, MN), equipped with a $0.32-\mathrm{m}^{2}$ spiralwound membrane. The temperature was kept constant at $10^{\circ} \mathrm{C}$ and controlled using a cooling water bath and a plate heat exchanger system. The UF membrane was polyethersulfone and had a molecular weight cutoff of $10 \mathrm{kDa}$ (Synder Filtration, Vacaville, CA). The RO membrane was polyamide and was characterized by a 99\% average $\mathrm{NaCl}$ rejection (General Electric, Trevose, $\mathrm{PA}$ ). The concentrating process was stopped at a volume concentration factor of $2.5 \times$.

\section{Sample Preparation}

Each batch of SM and concentrates was divided into 2 batches: one was kept at the initial $\mathrm{pH}$ (pHi), whereas the second was adjusted to $\mathrm{pH} 6.50$, which corresponds to the usual renneting $\mathrm{pH}$ for cheddar cheese (Ong et al., 2012). For the pH-adjusted batches, the $\mathrm{pH}$ was adjusted by adding D-gluconolactone (SigmaAldrich, St. Louis, MO) or $1 \mathrm{M} \mathrm{NaOH}$ (Thermo Fisher Scientific, Waltham, MA) to reach approximately $\mathrm{pH}$ 6.45 , and samples were equilibrated overnight at $4^{\circ} \mathrm{C}$. Before analyses or coagulation tests, the $\mathrm{pH}$ was readjusted, if necessary, with $1 \mathrm{M} \mathrm{NaOH}$ to reach 6.50 and samples were warmed to $32^{\circ} \mathrm{C}$ and held for $1 \mathrm{~h}$ at this temperature.

\section{Compositional Analyses}

Compositional analyses were done on both the sedimentable and nonsedimentable phases of milk or concentrate, which were separated by ultracentrifugation at $100,000 \times g$ for $1 \mathrm{~h}$ at $32^{\circ} \mathrm{C}$ (Ultracentrifuge Optima XE-90, Beckman Coulter, Brea, CA). The supernatant was carefully collected with a syringe after removing the thin layer of fat. The compounds found in the nonsedimentable phase were qualified as soluble, whereas the ones found in the sedimentable phase were qualified as colloidal.

Protein content was determined by the official microKjeldahl method. Total nitrogen, nonprotein nitrogen, and noncasein nitrogen fractions were determined (991.20, 998.05, and 991.21, respectively; AOAC International, 2000). A nitrogen-to-protein conversion factor of 6.38 was used.

Salt content ( $\mathrm{Ca}, \mathrm{Mg}, \mathrm{K}, \mathrm{Na}$, and $\mathrm{P}$ ) was determined by inductively coupled plasma-optical emission photometry from ashes. The samples (milk, concentrates, or permeates) were prepared by drying 1 to $3 \mathrm{~g}$ of 
sample overnight in an oven at $100^{\circ} \mathrm{C}$. The samples were transferred to a furnace oven (Furnace Furnatrol 1 Thermolyne, Thermo Fisher Scientific), where they were calcined overnight at $550^{\circ} \mathrm{C}$. The ashes were weighed, dissolved in $3 \mathrm{~mL}$ of $20 \%$ (wt/vol) trichloroacetic acid glacial (Anachemia, Radnor, PA), and diluted to $50 \mathrm{~g}$ with HPLC-grade water. After vortexing, the solutions were filtered with a $0.45-\mu \mathrm{m}$ filter (Starstedt, Nümbrecht, Germany) and sent for analysis. The ionic strength and salt activities were calculated as described by Lauzin et al. (2018).

\section{Rennet-Induced Coagulation}

The rennet-induced coagulation kinetics were studied by dynamic rheology as previously described (Lauzin et al., 2018). The storage modulus $\left(\mathbf{G}^{\prime}\right)$ values obtained were fitted to a sigmoid equation, as described by Perreault et al. (2016), to obtain the coagulation parameters: the tlag, which was the time needed for $\mathrm{G}^{\prime}$ to increase by $1 \mathrm{~Pa}$; the maximal firming rate; the time to reach the maximal firming rate; and the firmness at 60 $\min \left(\mathrm{G}^{\prime}\right.$ at $\left.60 \mathrm{~min}\right)$.

\section{Kinetics of $\mathrm{K}-\mathrm{CN}$ Hydrolysis}

The kinetics of $\kappa$-CN hydrolysis were studied as described by Sandra et al. (2011). Previously diluted rennet [EC 3.4.23.4; ChymO-plus, Fromagex, Rimouski, QC, Canada; 1/10 (vol/vol)] was added to milk or retentate at a final concentration of $0.1 \mathrm{~mL} / \mathrm{L}$. Immediately after renneting, the sample was divided into 2-mL aliquots and the reaction was stopped at the selected time by adding $4 \mathrm{~mL}$ of tricholoroacetic acid $3 \%$ (wt/vol; glacial tricholoroacetic acid, Anachemia) and mixing. Samples were stored at $4^{\circ} \mathrm{C}$ overnight and centrifuged at $4,500 \times g$ for $15 \mathrm{~min}$ at $4^{\circ} \mathrm{C}$ (Eppendorf centrifuge 5804R, Thermo Fisher Scientific). The supernatants were collected and filtered through $0.22-\mu \mathrm{m}$ polyvinylidene fluoride filter units (Chromspec, Brockville, ON, Canada).

Caseinomacropeptide (CMP) release was analyzed by reversed phase-HPLC. Volumes of $20 \mu \mathrm{L}$ were injected onto an Agilent 1100 series system (Santa Clara, CA) equipped with degasser, pump, autosampler, and UV detector (set to $214 \mathrm{~nm}$ ). Peptides were analyzed with a Luna $5-\mu \mathrm{m}$ C18 column $(2 \mathrm{~mm}$ i.d. $\times 250 \mathrm{~mm}$, Phenomenex, Torrance, CA) at $40^{\circ} \mathrm{C}$. Solvent A, $0.1 \%$ ( $\mathrm{vol} / \mathrm{vol})$ trifluoroacetic acid in water, and solvent B, acetonitrile/water/trifluoroacetic acid $[90 \% / 10 \% / 0.1 \%$ ( $\mathrm{vol} / \mathrm{vol})]$, were used for elution at a flow rate of 0.4 $\mathrm{mL} / \mathrm{min}$. A nonlinear gradient was used, where solvent B increased from 20 to $35 \%$ over 20 min, was held at $35 \%$ for $5 \mathrm{~min}$, and then increased to $65 \%$ over $25 \mathrm{~min}$

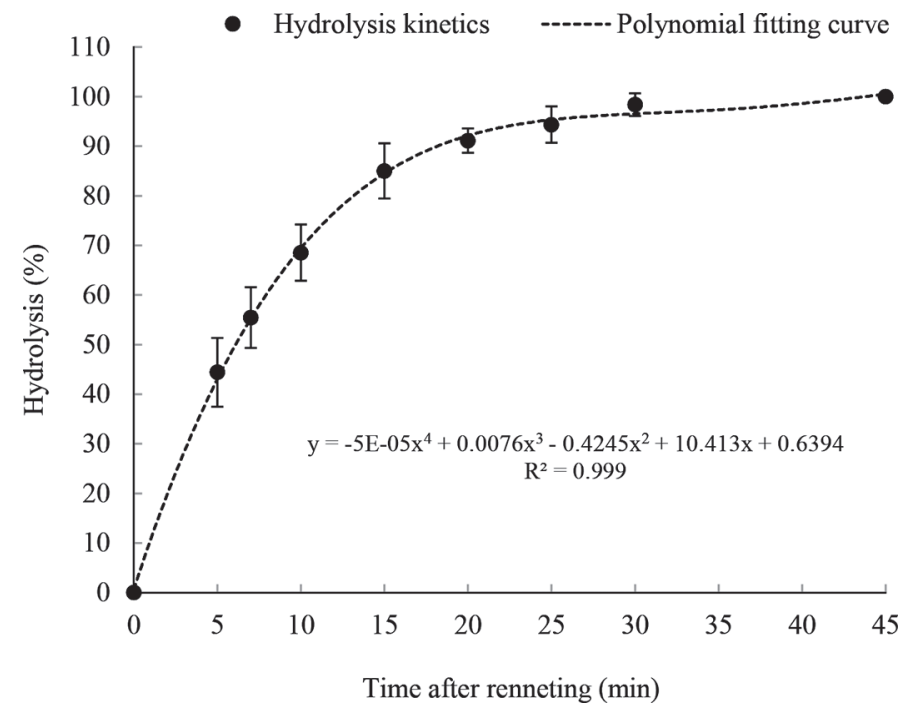

Figure 1. Example of hydrolysis kinetics of $\kappa-\mathrm{CN}$ by rennet (average of all treatments). Error bars indicate SD $(\mathrm{n}=3)$.

with a wash at $100 \%$ for 10 min. Data acquisition and peptide analysis (total peak area of the chromatograms) were done with LC/MSD ChemStation software Rev. A. 10.02 (Agilent).

Peptides were identified and quantified using standards made with pure CMP at different concentrations (Agropur, St-Hubert, QC, Canada). The $\kappa-C N$ hydrolysis data ( $\mathrm{mg}$ of CMP released per g of casein, as a function of time after renneting) were fitted using a polynomial curve as shown in Figure 1 (example). The standard curve equation was used to calculate the percentage of hydrolysis at the tlag of the different samples.

\section{Statistics}

The same batch of milk was used to produce both UF and RO concentrates. Three different batches (3 repetitions) of milk were used for the experiment. Each concentrate was divided into 2 portions: one was kept at the initial $\mathrm{pH}$, whereas the other was adjusted to $\mathrm{pH}$ 6.50. All analyses were done in triplicate. Average values and standard deviations are reported, as well as significant differences or similarities, which were evaluated using ANOVA with Tukey's test at a significance level of $\alpha=0.05$.

\section{RESULTS AND DISCUSSION}

\section{Sample Composition}

The overall composition of SM and concentrates is shown in Table 1. The UF and RO concentrates had similar true protein and casein contents, which were 
Table 1. Overall composition (mean $\pm \mathrm{SD}$ ) of skim milk and concentrates

\begin{tabular}{|c|c|c|c|}
\hline Item & Skim milk & UF concentrate & RO concentrate \\
\hline $\begin{array}{l}\text { True protein }(\mathrm{g} / 100 \mathrm{~g}) \\
\text { Casein }(\mathrm{g} / 100 \mathrm{~g}) \\
\text { Ash }(\mathrm{g} / 100 \mathrm{~g}) \\
\text { Calcium }(\mathrm{m} M) \\
\text { Phosphate }(\mathrm{m} M) \\
\text { pHi }^{2}\end{array}$ & $\begin{aligned} 3.06 & \pm 0.06^{\mathrm{b}} \\
2.61 & \pm 0.06^{\mathrm{b}} \\
0.690 & \pm 0.101^{\mathrm{c}} \\
25.99 & \pm 1.61^{\mathrm{c}} \\
25.68 & \pm 3.01^{\mathrm{c}} \\
6.59 & \pm 0.01^{\mathrm{a}}\end{aligned}$ & $\begin{aligned} 7.96 & \pm 0.91^{\mathrm{a}} \\
6.84 & \pm 0.82^{\mathrm{a}} \\
1.106 & \pm 0.085^{\mathrm{b}} \\
52.14 & \pm 5.55^{\mathrm{b}} \\
48.88 & \pm 4.87^{\mathrm{b}} \\
6.57 & \pm 0.02^{\mathrm{a}}\end{aligned}$ & $\begin{aligned} 7.51 & \pm 0.36^{\mathrm{a}} \\
6.44 & \pm 0.33^{\mathrm{a}} \\
1.830 & \pm 0.045^{\mathrm{a}} \\
60.34 & \pm 5.05^{\mathrm{a}} \\
64.63 & \pm 6.58^{\mathrm{a}} \\
6.33 & \pm 0.01^{\mathrm{b}}\end{aligned}$ \\
\hline
\end{tabular}

both significantly $(P<0.05)$ higher than SM. The RO concentrate had significantly $(P<0.05)$ higher ash, calcium, and phosphate content than the UF concentrate and SM due to higher membrane selectivity than UF. The UF concentrate also had higher $(P<$ 0.05) ash, calcium, and phosphate contents than SM due to the concentration of colloidal salts along with casein micelles. The pHi of SM and UF concentrates were similar (6.58), whereas the $\mathrm{pH}$ of $\mathrm{RO}$ concentrate was 0.25 units lower $(P<0.05)$ due to changes in salt equilibrium (Syrios et al., 2011).

To assess the effect of $\mathrm{pH}$ adjustment on the milk equilibria, the sedimentable and nonsedimentable phases were separated. The salt composition of concentrates and SM supernatants is presented in Table 2. Regardless of the $\mathrm{pH}$ value, the salt composition of the soluble phase of UF was similar to that of SM, as expected (Sandra et al., 2011). It is known that acidification of milk leads to modification of the equilibrium between the soluble and colloidal phases, as it causes some salts to solubilize from the micelles (Le Graët and Gaucheron, 1999). Le Graët and Gaucheron (1999) also showed that casein concentration affected the solubilization pattern of salts. In our study, adjusting the $\mathrm{pH}$ from pHi to 6.50 led to acidification of SM and UF concentrate, which can result in the solubilization of some salts from the micelle. However, the acidification was very minor, with a $\mathrm{pH}$ decrease of less than 0.1 unit, which could explain why no significant effect of $\mathrm{pH}$ on the salt equilibrium was observed.

At both $\mathrm{pH}$, the RO concentrate had a significantly $(P<0.05)$ higher concentration of all soluble salts than $\mathrm{SM}$ and UF concentrates due to the concentration of dissolved compounds during the process. Unlike the UF concentrate and $\mathrm{SM}$, it was necessary to increase the $\mathrm{pH}$ in the $\mathrm{RO}$ concentrate to 6.50 . Indeed, at $\mathrm{pH} 6.50$, the supernatant of the RO concentrate had a lower $(P<$ $0.05)$ concentration of soluble calcium $(15.01 \mathrm{mM})$ than at pHi $(21.04 \mathrm{mM})$. The concentration of magnesium and phosphate were also reduced by increasing the $\mathrm{pH}$ to $6.50(P<0.05)$. For the RO concentrate, increasing $\mathrm{pH}$ from 6.33 to 6.50 promoted the movement of salts from the soluble phase to the micelles. Compared with $\mathrm{pHi}$, the proportions of soluble calcium and phosphates decreased by 35 and $38 \%$, respectively, at $\mathrm{pH} 6.50$ (Table 3). Despite a reduced soluble salts content at $\mathrm{pH} 6.50$, the ionic strength of the RO concentrate was not affected by $\mathrm{pH}$; it was, however, significantly higher $(P<0.05)$ than in UF concentrate and SM at both $\mathrm{pH}$ (Table 2).

Table 2. Composition (mean $\pm \mathrm{SD}$ ) of supernatants of skim milk and concentrates at initial and adjusted $\mathrm{pH}$

\begin{tabular}{|c|c|c|c|c|c|c|}
\hline Item & \multicolumn{3}{|c|}{$\mathrm{pHi}^{1}$} & \multicolumn{3}{|c|}{$\mathrm{pH} 6.50$} \\
\hline True protein $(\mathrm{g} / 100 \mathrm{~g})$ & $0.64 \pm 0.01^{\mathrm{c}}$ & $2.00 \pm 0.27^{\mathrm{a}}$ & $1.93 \pm 0.22^{\mathrm{ab}}$ & $0.58 \pm 0.06^{\mathrm{c}}$ & $1.85 \pm 0.28^{\mathrm{ab}}$ & $1.71 \pm 0.20^{\mathrm{b}}$ \\
\hline Casein $(\mathrm{g} / 100 \mathrm{~g})$ & $0.06 \pm 0.04^{\mathrm{c}}$ & $0.43 \pm 0.04^{\mathrm{b}}$ & $0.64 \pm 0.10^{\mathrm{a}}$ & $0.14 \pm 0.05^{\mathrm{c}}$ & $0.57 \pm 0.12^{\mathrm{a}}$ & $0.53 \pm 0.10^{\mathrm{ab}}$ \\
\hline \multicolumn{7}{|l|}{ Salt content $(\mathrm{m} M)$} \\
\hline $\mathrm{Ca}$ & $9.32 \pm 0.25^{\mathrm{c}}$ & $10.21 \pm 1.92^{\mathrm{c}}$ & $21.04 \pm 3.71^{\mathrm{a}}$ & $9.04 \pm 0.67^{\mathrm{c}}$ & $10.98 \pm 0.23^{\mathrm{c}}$ & $15.01 \pm 0.92^{\mathrm{b}}$ \\
\hline $\mathrm{K}$ & $33.06 \pm 0.53^{\mathrm{b}}$ & $26.12 \pm 8.58^{\mathrm{b}}$ & $83.46 \pm 3.44^{\mathrm{a}}$ & $29.38 \pm 0.98^{\mathrm{b}}$ & $32.02 \pm 4.02^{\mathrm{b}}$ & $84.34 \pm 12.39^{\mathrm{a}}$ \\
\hline $\mathrm{PO}_{4}$ & $14.71 \pm 0.38^{\mathrm{c}}$ & $14.54 \pm 2.74^{\mathrm{c}}$ & $35.98 \pm 5.50^{\mathrm{a}}$ & $14.18 \pm 0.53^{\mathrm{c}}$ & $18.13 \pm 3.08^{\mathrm{c}}$ & $28.53 \pm 1.93^{\mathrm{b}}$ \\
\hline Ionic strength $(\mathrm{m} M)$ & $69.19 \pm 5.31^{\mathrm{b}}$ & $71.87 \pm 3.90^{\mathrm{b}}$ & $147.30 \pm 1.24^{\mathrm{a}}$ & $71.26 \pm 1.87^{\mathrm{b}}$ & $76.33 \pm 0.44^{\mathrm{b}}$ & $147.95 \pm 0.64^{\mathrm{a}}$ \\
\hline
\end{tabular}

${ }^{\mathrm{a}-\mathrm{c}}$ Means within a row with different superscripts differ $(P<0.05)$.

${ }^{1}$ Initial $\mathrm{pH}$.

${ }^{2}$ Reverse osmosis concentrate. 
Casein equilibrium is also affected by environmental changes, such as variations in $\mathrm{pH}$. Table 2 shows the soluble true protein and casein compositions of the supernatants of concentrates and $\mathrm{SM}$ at $\mathrm{pHi}$ and $\mathrm{pH} 6.50$. The proteins in the supernatant are mainly whey proteins, which have been concentrated along with casein during filtration. Hence, the concentrations of those proteins were similar in both UF and RO concentrates and higher $(P<0.05)$ than in SM; they were also not affected by $\mathrm{pH}$ adjustment. At $\mathrm{pHi}$, the concentration of soluble caseins was higher in the concentrates, with 0.43 (6\% of total casein) and $0.64 \mathrm{~g} / 100 \mathrm{~g}$ (10\% of total casein) for UF and RO concentrates, respectively, whereas SM was only $0.06 \mathrm{~g} / 100 \mathrm{~g}$ (2\% of total casein). Soluble caseins were concentrated during these processes and some casein dissociation may have occurred during milk concentration or due to the final properties of the concentrates, such as the higher ionic strength in the RO concentrate (Gaucheron et al., 2004). Adjusting the $\mathrm{pH}$ to 6.50 did not significantly change the amount of soluble casein for SM, even though it was slightly higher at pH $6.50(0.14 \mathrm{~g} / 100 \mathrm{~g}$, or $5 \%$ of total casein). The amount of soluble casein in the UF concentrate increased significantly $(P<0.05)$ after $\mathrm{pH}$ adjustment to 6.50 , with $0.57 \mathrm{~g} / 100 \mathrm{~g}$ ( $8 \%$ of total casein), which is consistent with the dissociation of caseins from the micelles when the $\mathrm{pH}$ decreases (Dalgleish and Law, 1988). Reduced concentration of soluble casein in RO concentrate was expected after increasing the $\mathrm{pH}$ to 6.50 but the effect of the $\mathrm{pH}$ change was not statistically significant $(P>0.05)$.

The colloidal calcium concentration was not affected by UF concentration or $\mathrm{pH}$ adjustment and averaged $26.8 \mathrm{mg}$ of colloidal calcium per gram of colloidal casein. The concentration of colloidal calcium in RO concentrate at $\mathrm{pHi}$ was not significantly higher than after $\mathrm{pH}$ adjustment. Calcium transfer from the soluble to the colloidal phase was expected during RO concentration, but the lower $\mathrm{pH}$ and higher ionic strength after concentration (Table 2) increased the calcium and phosphate activities in the soluble phase, which reduced calcium transfer to the casein micelles. However, the $\mathrm{pH}$ adjustment of RO concentrate from 6.33 to 6.50 significantly increased the insoluble calcium fraction concentration to $30.6 \mathrm{mg} / \mathrm{g}(P<0.05)$. This result is consistent with the well-known effect of increasing $\mathrm{pH}$ on milk mineral equilibrium (Le Graet and Brulé, 1993).

\section{Rennet-Gelation Properties and CMP Release}

The rennet-gelation properties are summarized in Table 4 . At pHi, significantly different tlag were observed for SM and concentrates $(P<0.05)$. Skim milk had the longest tlag (36 $\mathrm{min})$, followed by UF concentrate (23 $\mathrm{min}$ ) and RO concentrate $(11 \mathrm{~min})$. Some authors have observed that the use of UF concentrate negatively affects gelation time compared with SM (Culioli and Sherman, 1978; Karlsson et al., 2007b). The shorter tlag obtained for RO concentrate compared with SM and UF concentrate must be due to the lower $\mathrm{pH}$ of the RO concentrate, which promotes faster coagulation. After adjusting the $\mathrm{pH}$ to 6.50 , the tlag of SM and UF concentrates decreased to a similar value of $14.5 \mathrm{~min}$, whereas the tlag of RO concentrate increased and was significantly longer than those of SM and UF concentrate $(P<0.05)$. It has been shown that reducing the $\mathrm{pH}$ decreases colloidal calcium phosphate and increases the soluble calcium activity, and that these 2 factors have opposite effects on tlag (Shalabi and Fox, 1982). However, under the conditions of our study, the $\mathrm{pH}$ decrease for SM and UF concentrate was lower than 0.1 unit and did not induce significant changes in soluble or colloidal calcium concentrations (Table 3). Rennet activity might have been increased by this slight $\mathrm{pH}$

Table 3. Distribution (mean $\pm \mathrm{SD}$ ) of the main salts and salt activities at initial $\mathrm{pH}$ and adjusted $\mathrm{pH}$

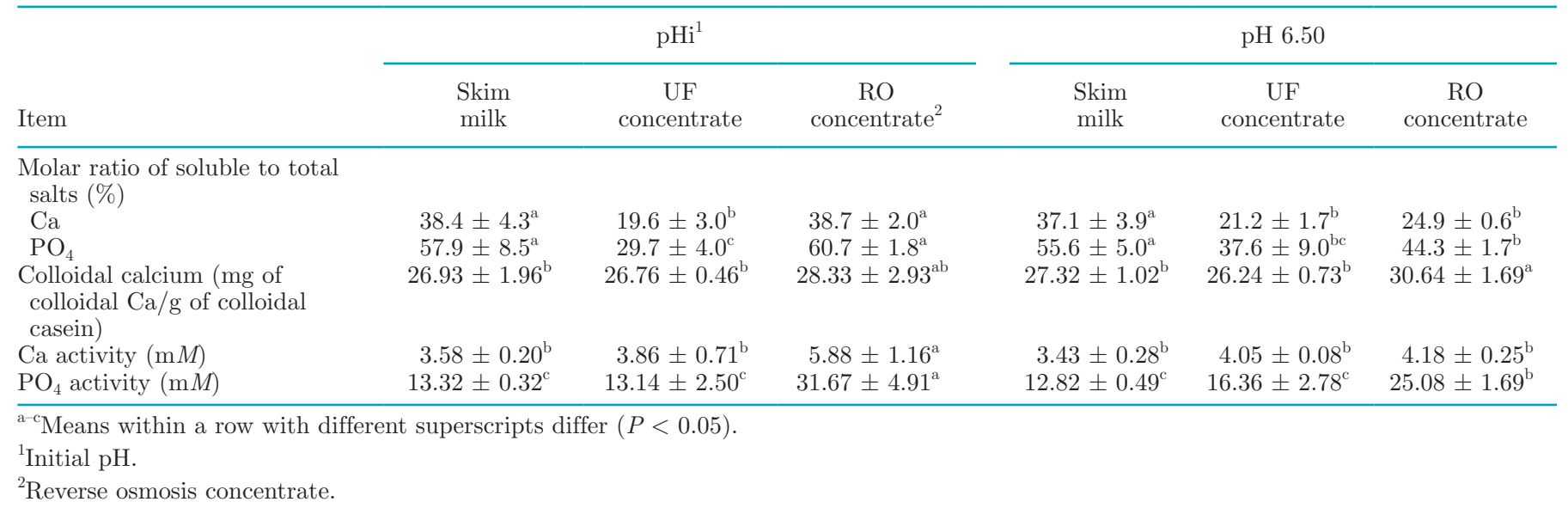


Table 4. Rennet coagulation parameters (mean $\pm \mathrm{SD}$ ) of skim milk (SM) and concentrates at initial and adjusted $\mathrm{pH}$

\begin{tabular}{|c|c|c|c|c|c|c|}
\hline Parameter $^{1}$ & \multicolumn{3}{|c|}{$\mathrm{pHi}^{2}$} & \multicolumn{3}{|c|}{ pH 6.50} \\
\hline tlag (min) & $36.09 \pm 0.97^{\mathrm{a}}$ & $22.99 \pm 2.78^{\mathrm{b}}$ & $11.49 \pm 1.68^{\mathrm{c}}$ & $14.51 \pm 1.25^{\mathrm{c}}$ & $14.51 \pm 0.14^{\mathrm{c}}$ & $19.54 \pm 1.80^{\mathrm{b}}$ \\
\hline Time to Vmax (min) & $67.55 \pm 3.21^{\mathrm{a}}$ & $40.54 \pm 5.86^{\mathrm{b}}$ & $32.64 \pm 2.13^{\mathrm{c}}$ & $34.05 \pm 5.98^{\mathrm{c}}$ & $28.95 \pm 0.78^{\mathrm{c}}$ & $42.19 \pm 1.66^{\mathrm{b}}$ \\
\hline $\mathrm{G}^{\prime}$ at $60 \min (\mathrm{Pa})$ & $8.53 \pm 0.96^{\mathrm{d}}$ & $401.29 \pm 91.62^{\mathrm{b}}$ & $732.20 \pm 12.33^{\mathrm{a}}$ & $58.82 \pm 8.38^{\mathrm{c}}$ & $692.08 \pm 62.64^{\mathrm{a}}$ & $527.10 \pm 77.61^{\mathrm{b}}$ \\
\hline Viscosity (at $100 \mathrm{~s} ; \mathrm{mPa} / \mathrm{s}$ ) & $1.34 \pm 0.02^{\mathrm{c}}$ & $2.65 \pm 0.31^{\mathrm{b}}$ & $3.05 \pm 0.14^{\mathrm{a}}$ & $1.33 \pm 0.00^{\mathrm{c}}$ & $2.58 \pm 0.32^{\mathrm{b}}$ & $3.32 \pm 0.31^{\mathrm{a}}$ \\
\hline
\end{tabular}

${ }^{\mathrm{a}-\mathrm{d}}$ Means within a row with different superscripts differ $(P<0.05)$.

${ }^{1}$ Parameters: tlag $=$ rennet coagulation time; Vmax $=$ maximal firming rate; $\mathrm{G}^{\prime}$ at $60 \mathrm{~min}=$ firmness at 60 min; hydrolysis at tlag $=$ degree of hydrolysis at coagulation point.

${ }^{2}$ Initial $\mathrm{pH}$.

${ }^{3}$ Reverse osmosis concentrate.

change or the charge repulsions between casein micelles might have decreased (Shalabi and Fox, 1982; Awad, 2007). The tlag of RO concentrate was 8 min longer after increasing the $\mathrm{pH}$ from 6.33 to 6.50 (Table 4). Increasing the $\mathrm{pH}$ of $\mathrm{RO}$ concentrate significantly reduced the calcium activity (Table 3 ), which explains the longer tlag (Sandra et al., 2012). Increased charge repulsions between casein micelles and lower enzyme activity at higher $\mathrm{pH}$ may also have contributed to slow aggregation.

As tlag is a sum of the hydrolysis and aggregation phases (Dalgleish, 1980), CMP release after renneting was studied to determine whether the $\kappa$ - $\mathrm{CN}$ hydrolysis rate or the aggregation rate or both were affected by concentration and $\mathrm{pH}$ adjustment. The kinetics of k-CN hydrolysis were not significantly affected by milk concentration or $\mathrm{pH}$ adjustment $(P>0.05)$, indicating that the enzymatic phase was not responsible for tlag differences under the conditions used in our study. An average kinetics curve of $\kappa$-CN hydrolysis is presented in Figure 1 and the fitting curve equation was used to calculate the extent of hydrolysis required to trigger milk coagulation (Table 4 ).

At pHi, significantly $(P<0.05)$ different degrees of hydrolysis at coagulation point were observed for SM (96\%), UF concentrate (93\%), and RO concentrate (74\%). Milk gelation occurs when sufficient $\kappa-\mathrm{CN}$ has been hydrolyzed so that the natural electrostatic repulsions between micelles (and the steric stabilization) are reduced and the hydrophobic attractions between paracasein micelles predominate (Lucey et al., 2003). Greater $\kappa-\mathrm{CN}$ hydrolysis at the coagulation point indicates more stabilized micelles where further destabilization is required to promote interactions between rennet-altered micelles. At pHi, SM and UF concentrates had different degrees of hydrolysis at the coagulation point despite having similar $\mathrm{pH}$ values. The use of UF concentrate is expected to lead to a lower CMP release to trigger gelation, as already observed for UF concentrate compared with SM, due to increased collision frequency as well as higher ionic calcium content (Karlsson et al., 2007b). However, some authors found no difference in the kinetics of CMP release of UF concentrates and SM (Salvatore et al., 2011; Sandra et al., 2011). Different experimental procedures and milk treatment history could be responsible for the reported differences in the literature (Salvatore et al., 2011). In our case, the slightly lower $\mathrm{pH}$ (not significant) of UF concentrate as compared with SM may be responsible for decreasing the charge of the stabilizing layer promoting gelation at lower degree of hydrolysis. At pHi, the $\mathrm{RO}$ concentrate had the lowest $\mathrm{pH}$ value, the lowest degree of hydrolysis needed to reach tlag, and the shortest tlag. At this $\mathrm{pH}$, the soluble calcium content and the calcium activity were higher $(P<0.05)$ than in any other sample, which could explain the lower degree of hydrolyzed $\kappa$-CN needed to start gelation. It is well known that addition of calcium chloride leads to higher soluble calcium and a lower degree of hydrolysis needed to reach the coagulation point (Sandra et al., 2012). Furthermore, the low $\mathrm{pH}$ of this concentrate is likely responsible for decreased electrostatic repulsion between casein micelles which would promote interaction and aggregation of micelles (Lucey et al., 2003).

At $\mathrm{pH}$ 6.50, the percentage of hydrolyzed micelles needed to start aggregation and reach the coagulation point was similar for SM and UF concentrates, as previously observed (Sandra et al., 2011; Zhao and Corredig, 2016). At this $\mathrm{pH}$, the RO concentrate had more $(P<$ 0.05 ) hydrolysis at the coagulation point than the SM and UF concentrates. Hence, in the RO concentrate the hydrolyzed micelles had an increased stability, leading to a higher degree of hydrolysis needed to reach the gelation point. At his $\mathrm{pH}$, the main compositional difference with UF concentrates is the higher lactose and higher soluble salts contents of RO concentrate, lead- 
ing to increased viscosity and ionic strength. Increased sucrose content has been shown to increase the degree of hydrolysis at gelation point, and the high lactose concentration in our study might be responsible for the stabilization effect observed (Famelart, 1994). It has also been shown that high ionic strengths resulting from $\mathrm{NaCl}$ addition led to longer coagulation times (Karlsson et al., 2007a; Zhao and Corredig, 2016), but no effect on the degree of $\kappa$-CN hydrolyzed at the coagulation point was observed (Famelart et al., 1999; Karlsson et al., 2007a).

The maximal firming rate (Vmax) was significantly affected by the concentration process and $\mathrm{pH}$ adjustment $(P<0.05)$. At pHi, SM had the lowest Vmax $(0.47 \mathrm{~Pa} / \mathrm{min})$, followed by UF concentrate $(15.65 \mathrm{~Pa} /$ min) and $\mathrm{RO}$ concentrate $(27.63 \mathrm{~Pa} / \mathrm{min})$. At $\mathrm{pH} 6.50$, $\mathrm{UF}$ and RO concentrates had similar Vmax of about $21 \mathrm{~Pa} / \mathrm{min}$, whereas the Vmax of SM was significantly lower. As expected, the firming rate was much higher in UF and RO concentrates than in SM. Soodam and Guinee (2018) reported that the gel-firming rate increased exponentially with the concentration of casein. Skim milk and UF concentrate had higher firming rates at $\mathrm{pH} 6.50$ than at $\mathrm{pHi}$, whereas the opposite was true for $\mathrm{RO}$ concentrate. Overall, decreasing the $\mathrm{pH}$ led to increased firming rates whereas increasing the $\mathrm{pH}$ led to reduced firming rates. This result is consistent with Castillo et al. (2000), who found that decreasing the $\mathrm{pH}$ led to an increased Vmax and a higher rate of rearrangement. The time to reach Vmax was affected by both the concentration process and the $\mathrm{pH}$ adjustment. At $\mathrm{pHi}$, the time to reach Vmax was significantly higher $(P<0.05)$ for SM and UF concentrate, at 68 and 41 min, respectively, versus 33 min for RO concentrate. At $\mathrm{pH}$ 6.50, the time to reach Vmax was similar for SM and UF concentrate $(\sim 31.5 \mathrm{~min})$, and higher for RO concentrate $(42.2 \mathrm{~min} ; P<0.05)$. Increasing $\mathrm{pH}$ led to increased time to reach Vmax, and the opposite was true when the $\mathrm{pH}$ was reduced.

The $\mathrm{G}^{\prime}$ at $60 \mathrm{~min}$ was affected by the type of milk and concentrates used and the $\mathrm{pH}$ adjustment made. Gels made from concentrates had higher $\mathrm{G}^{\prime}$ values at 60 min than gels made from SM, regardless of the $\mathrm{pH}$ used, due to the higher casein content (closer proximity) and the increased number of bonds between caseins (Sandra et al., 2011). At pHi, the $\mathrm{G}^{\prime}$ values ranged from $732 \mathrm{~Pa}$ (RO concentrate) to $8.5 \mathrm{~Pa}(\mathrm{SM})$. At the adjusted $\mathrm{pH}$, the $\mathrm{UF}$ concentrate had the highest $\mathrm{G}^{\prime}$ value (692 Pa), similar to the RO concentrate at $\mathrm{pHi}$, and $\mathrm{SM}$ had the lowest $\mathrm{G}^{\prime}$ value (59 Pa). The RO concentrate had an intermediate $\mathrm{G}^{\prime}$ value of about $527 \mathrm{~Pa}$, similar to the UF concentrate at pHi. Increasing the $\mathrm{pH}$ led to reduced $\mathrm{G}^{\prime}$ at $60 \mathrm{~min}$, as previously observed (Zoon et al., 1989; Awad, 2007). The rennet-gelation behavior of the UF concentrate at $\mathrm{pH} 6.50$ was similar to the RO concentrate at $\mathrm{pHi}$, despite important compositional differences.

Finally, the viscosity was also affected by the concentration process, as SM had the lowest viscosity and RO concentrate the highest. These results are similar to those obtained in our previous study with concentrates made at $50^{\circ} \mathrm{C}$ (Lauzin et al., 2018). The viscosity was unaffected by $\mathrm{pH}$ modification, which correlated with the limited compositional changes observed in the soluble phase.

\section{CONCLUSIONS}

The aim of our study was to investigate the effect of adjusting the $\mathrm{pH}$ (initial $\mathrm{pH}$ vs. 6.50) of SM, UF, and RO concentrates on their rennet-coagulation properties. The $\mathrm{pH}$ adjustment step did not have a major effect on the composition of the soluble phase or on the equilibrium between the colloidal and soluble phases for SM and UF concentrate, whereas RO concentrate had higher soluble calcium, magnesium, and phosphate contents at initial $\mathrm{pH}$ than at $\mathrm{pH}$ 6.50. The changes in rennet-gelation properties resulting from $\mathrm{pH}$ adjustment were important, despite the relatively small $\mathrm{pH}$ changes $(<0.2 \mathrm{pH}$ unit). All samples at both $\mathrm{pH}$ had similar rennet hydrolysis kinetics. At $\mathrm{pH}$ 6.50, RO concentrate had impaired rennet-gelation behavior compared with UF concentrate, with a higher degree of $\kappa$-CN hydrolysis at the coagulation point. As the pHi of RO concentrate was lower than 6.50, its coagulation properties were better at $\mathrm{pHi}$ and similar to those obtained with UF concentrate at $\mathrm{pH} 6.50$, despite major compositional differences. The lower $\mathrm{pHi}$ in $\mathrm{RO}$ concentrate led to increased calcium activity and reduced electrostatic repulsions between micelles, which promoted aggregation at a lower degree of $\kappa-\mathrm{CN}$ hydrolysis. With a slight $\mathrm{pH}$ variation, it was possible to obtain different rennet-gelation behavior for the concentrates studied; however, it would still be of interest to investigate which compound(s) is responsible for the different rennet-gelation behavior of the concentrates at the same $\mathrm{pH}$ to better understand these concentrates.

\section{ACKNOWLEDGMENTS}

This work was supported by the Natural Sciences and Engineering Research Council of Canada (NSERC), Novalait Inc., Fonds de recherche du Québec-Nature et technologies (FRQNT), and the Canadian Dairy Commission (CDC, Ottawa, ON, Canada). The authors thank Diane Gagnon, Mélanie Martineau, and Pascal 
Lavoie from the Department of Food Science at Laval University (Québec, QC, Canada) for their assistance during the experiments.

\section{REFERENCES}

AOAC International. 2000. Official Methods of Analysis. 17th ed. AOAC Int., Gaithersburg, MD.

Awad, S. 2007. Effect of sodium chloride and $\mathrm{pH}$ on the rennet coagulation and gel firmness. Lebensm. Wiss. Technol. 40:220-224.

Castillo, M., F. A. Payne, C. L. Hicks, and M. B. Lopez. 2000. Predicting cutting and clotting time of coagulating goat's milk using diffuse reflectance: Effect of $\mathrm{pH}$, temperature and enzyme concentration. Int. Dairy J. 10:551-562.

Culioli, J., and P. Sherman. 1978. Rheological aspects of the renneting of milk concentrated by ultrafiltration. J. Texture Stud. 9:257-281.

Dalgleish, D. G. 1980. Effect of milk concentration on the rennet coagulation time. J. Dairy Res. 47:231-235.

Dalgleish, D. G., and A. J. R. Law. 1988. pH-Induced dissociation of bovine casein micelles. I. Analysis of liberated caseins. J. Dairy Res. 55:529-538.

Famelart, M. H. 1994. Rennet coagulation of milk in the presence of sucrose. J. Dairy Res. 61:473-483. https://doi.org/10.1017/ S0022029900028405.

Famelart, M. H. H., Y. Le Graet, and K. Raulot. 1999. Casein micelle dispersions into water, $\mathrm{NaCl}$ and $\mathrm{CaCl}$ : physicochemical characteristics of micelles and rennet coagulation. Int. Dairy J. 9:293-297.

Gaucheron, F., Y. Le Graët, and P. Schuck. 2004. Equilibres minéraux et conditions physicochimiques. Lavoisier, Tech \& Doc, Paris, France.

Guinee, T. P., C. B. Gorry, D. J. O'Callaghan, B. T. O'Kennedy, N. O'Brien, and M. A. Fenelon. 1997. The effects of composition and some processing treatments on the rennet coagulation properties of milk. Int. J. Dairy Technol. 50:99-106.

Karlsson, A. O., R. Ipsen, and Y. Ardö. 2007a. Influence of pH and $\mathrm{NaCl}$ on rheological properties of rennet-induced casein gels made from UF concentrated skim milk. Int. Dairy J. 17:1053-1062.

Karlsson, A. O., R. Ipsen, and Y. Ardö. 2007b. Rheological properties and microstructure during rennet induced coagulation of UF concentrated skim milk. Int. Dairy J. 17:674-682.

Lauzin, A., I. Dussault-Chouinard, M. Britten, and Y. Pouliot. 2018 Impact of membrane selectivity on the compositional characteristics and model cheese-making properties of liquid pre-cheese concentrates. Int. Dairy J. 83:34-42.

Le Graet, Y., and G. Brulé. 1993. Les équilibres minéraux du lait: Influence du $\mathrm{pH}$ et de la force ionique. Lait 73:51-60.

Le Graët, Y., and F. Gaucheron. 1999. pH-induced solubilization of minerals from casein micelles: influence of casein concentration and ionic strength. J. Dairy Res. 66:215-224.

Lucey, J. A., M. E. E. Johnson, and D. S. Horne. 2003. Invited review: Perspectives on the basis of the rheology and texture properties of cheese. J. Dairy Sci. 86:2725-2743.
Mistry, V. V., and J.-L. Maubois. 2004. Application of Membrane Separation Technology to Cheese Production. 3rd ed. Elsevier, Amsterdam, the Netherlands.

Ong, L., R. R. Dagastine, M. A. E. Auty, S. E. Kentish, and S. L. Gras. 2011. Coagulation temperature affects the microstructure and composition of full fat Cheddar cheese. Dairy Sci. Technol. 91:739-758. https://doi.org/10.1007/s13594-011-0033-6.

Ong, L., R. R. Dagastine, S. E. Kentish, and S. L. Gras. 2012. The effect of $\mathrm{pH}$ at renneting on the microstructure, composition and texture of Cheddar cheese. Food Res. Int. 48:119-130.

Perreault, V., O. Turcotte, P. Morin, Y. Pouliot, and M. Britten. 2016. Combined effect of denatured whey protein concentrate level and fat level in milk on rennet gel properties. Int. Dairy J. 55:1-9.

Salvatore, E., A. Pirisi, and M. Corredig. 2011. Gelation properties of casein micelles during combined renneting and bacterial fermentation: Effect of concentration by ultrafiltration. Int. Dairy J. $21: 848-856$.

Sandra, S., C. Cooper, M. Alexander, and M. Corredig. 2011. Coagulation properties of ultrafiltered milk retentates measured using rheology and diffusing wave spectroscopy. Food Res. Int. 44:951-956.

Sandra, S., M. Ho, M. Alexander, and M. Corredig. 2012. Effect of soluble calcium on the renneting properties of casein micelles as measured by rheology and diffusing wave spectroscopy. J. Dairy Sci. 95:75-82.

Shalabi, S. I., and P. F. Fox. 1982. Influence of $\mathrm{pH}$ on the rennet coagulation of milk. J. Dairy Res. 49:153-157.

Sharma, S. K., A. R. Hill, and G. S. Mittal. 1993. Effect of milk concentration, $\mathrm{pH}$ and temperature on aggregation kinetics and coagulation properties of ultrafiltered (UF) milk. Food Res. Int. 26:81-87.

Soodam, K., and T. P. Guinee. 2018. The case for milk protein standardisation using membrane filtration for improving cheese consistency and quality. Int. J. Dairy Technol. 71:277-291.

Syrios, A., M. Faka, A. S. Grandison, and M. J. Lewis. 2011. A comparison of reverse osmosis, nanofiltration and ultrafiltration as concentration processes for skim milk prior to drying. Int. J. Dairy Technol. 64:467-472.

Waungana, A., H. Singh, and R. J. Bennet. 1998. Rennet coagulation properties of skim milk concentrated by ultrafltration: Effects of heat treatment and pH adjustment. Food Res. Int. 31:645-651.

Wium, H., P. S. Pedersen, and K. B. Qvist. 2003. Effect of coagulation conditions on the microstructure and the large deformation properties of fat-free feta cheese made from ultrafiltered milk. Food Hydrocoll. 17:287-296. https://doi.org/10.1016/S0268 $-005 X(02) 00079-6$.

Zhao, Z., and M. Corredig. 2016. Influence of sodium chloride on the colloidal and rennet coagulation properties of concentrated casein micelle suspensions. J. Dairy Sci. 99:6036-6045.

Zoon, P., T. Van Vilet, and P. Walstra. 1989. Rheological properties of rennet-induced skim milk gels. 4 . The effect of $\mathrm{pH}$ and $\mathrm{NaCl}$. Neth. Milk Dairy J. 43:17-34. 